unwearied industry to the collection and comparison of the Cephalopods of the Lias, and at length, after some forty years of preparation, began his great monograph on "The Lias Ammonites," a work of much research, of which the concluding part is about to be issued, and which forms an enduring landmark in the history of English palæontology. In the course of the inquiries rendered requisite for this exhaustive treatise, he not only made himself acquainted with the fossil localities and public and private collections in this country, but paid visits to many parts of the Continent to study the contents of foreign museums and to confer with his fellowlabourers in the same field scattered over France, Switzerland, and Germany. $\mathrm{He}$ was engaged, at the time of his death, upon a monograph of British Cretaceous Starfishes, which he had nearly completed.

The value of his scientific work has been fully recognised by his contemporaries. He was early elected as a Fellow of the Royal Society of Edinburgh. Subsequently he joined the Geological Society of London, and from that body eventually received its highest honour-the Wollaston Medal. In 1879 he was elected into the Royal Society. He was President of the Geological Section of the British Association at the Bristol meeting in 1875 . His published papers and memoirs are numerous, but the largest and most important are his monographs in the publications of the Palacontographical Society.

It was not alone by original research that $\mathrm{Dr}$. Wright strove to foster the progress of his favourite science. As one of the fathers of the Cotteswold Field Club, as President of the Literary and Philosophical Association of Cheltenham, as a frequent lecturer on scientific topics not only in Cheltenham, but in Bristol, Bath, Worcester, and other towns; and generally by the enthusiasm with which, amid all the obstacles of his busy professional life, he contrived to find leisure for the cultivation of science, he was unqucstionably one of the living forces that stimulated the growth of science all over the West of England. His death is therefore a serious deprivation, and will be mourned by all in that region to whom scientific progress is dear.

To a narrower but still a wide circle his removal from among us is the loss of a leal-hearted friend. Those who were thus privileged will cherish the memory of that cheery face with the bright twinkle of eyes that were as brimful at one time of merriment as, at another, they were suffused with sympathy; the joyous laughter that rang out clear and strong from a heart in which there was no guile; the earnest brow and hand upturned behind the ear as the talk went on over his favourite pursuits ; the bursts of enthusiasm as some new fact or novel deduction dawned on him, and the play of humour that was ever ready to break out like a beam of summer sunshine. Dr. Wright made his final expedition in August last ycar, when he joined the writer of these lines in the Island of Arran. Already the symptoms of his fatal malady had shown themselves, and he knew what they foreboded. But he carried with him nevertheless his characteristic sumniness of nature. Seated on the bare mountain-side with the purple heather and vellowed bracken around him, the sea in front, and his own native Renfrewshire hills in the blue distance, he became almost a boy again as he told his reminiscences of old times and watched the sports of children among the gray boulders. Ripe in honours as in years, it seemed as if he had come back to his early northern air to drink it once more, and review his past before he should quit us for ever. $\mathrm{He}$ would saunter for hours in the quiet glen, with no companion but his own thoughts and the sights and sounds of Nature, which were an ever-gushing fountain of pleasure to him. Cherished is every memory of him, but most of all those parting days spent with him at the foot of the mountains and by the shore of the restless sea.

\section{ROBERT A. C. GODWIN-AUSTEN, F.R.S.}

$\mathrm{I} N$ many respects $\mathrm{Mr}$. Godwin-Austen stood out apart from his fellow-geologists in this country. He wrote comparatively little, but what he did write was always weighty and full of suggestiveness. Instead of loading the literature of science with a pile of little papers, each containing some trifling addition or supposed addition to the sum of knowledge, or some criticism well- or illfounded of the work of others, he allowed his ideas to maturc, and published them from time to time in luminous essays which many years afterwards may be read over again with profit as well as pleasure. $\mathrm{He}$ began to write about half a century ago, his earliest papers being devoted to the geological features of Devonshire, of which, at that time, very little was known. By degrees he extended the area of his observations eastwards into the south-eastern counties. His essays "On the Valley of the English Channel" (I850), and "On the Superficial Accumulations of the Coasts of the English Channel, and the changes which they indicate" (185I), were among the most thoughtful contributions that had ever been made to the elucidation of the existing outlines of sea and land. This department of inquiry was one that peculiarly fascinated him. Hence, when his friend Edward Forbes died and left his "Natural History of the European Seas" only half completed, he himself chivalrously finished it, and supplied some chapters which only an accomplished and far-sighted geologist could have written. His various papers on drift-gravels, on boulders in the Chalk, and other superficial phenomena, are all marked by the same grasp and breadth of treatment.

But perhaps the paper which has chiefly contributed to give Mr. Godwin-Austen his ascendency among English geologists and to make his name known beyond geologica! circles is his now well-known essay "On the Possible Extension of the Coal-Measures beneath the South-Eastern Part of England " (1855). In this remarkable memoir he brings to bear his detailed knowledge of the rocks of the south-west of England, the north of France, and the adjoining tracts of Belgium. He marshals all his facts in such a way as to enable us, as it were, to strip off the thick cover of Mesozoic formations and trace the deep-seated connection of the Palæozoic area of Southern England and the Continent. At the time when he wrote, nothing was actually known of the subject, but he predicted that a submerged Palieozoic ridge would be found extending from the south-west of England into France and Belgium. The results of the deep borings of recent years have fully verificd this prediction.

Mr. Godwin-Austen, in his prime, was a frequent speaker at the meetings of the Geological Society, where his keen penetrative criticism and caustic sarcasm formed a prominent and valuable feature in the debates. Some of his most suggestive and pregnant views of geological questions were thrown off in the course of these debates, and were never otherwise published by him. He never courted publicity, but rather shrank from it as an incumbrance under which he would not willingly be fettered. For many years past he has lived as a retired country squire at his beautiful residence near Guildford, taking full interest in the progress of science, and glad to see his fellow-workers in geology under his roof, but seldom venturing into the turmoil of town and the disputatious atmosphere of learned societies. It is some consolation to geologists, who mourn the quenching of one of their luminaries, that his place is taken by a son who, by scientific labours in India and in this country, has proved himself a worthy successor.

\section{CHARLES CLOUSTON}

THE Rev. Chas. Clouston, LL.D., of Sandwick Manse, near Stromness, who died on the roth ult. at the very advanced age of eighty-four years, was a man who 